\begin{tabular}{|c|c|c|c|c|c|c|}
\hline \multirow{4}{*}{ Impact Factor: } & ISRA (India) & $=3.117$ & SIS (USA) & $=0.912$ & ICV (Poland) & $=6.630$ \\
\hline & ISI (Dubai, UAE & $=0.829$ & РИНЦ (Russia) & $=0.156$ & PIF (India) & $=1.940$ \\
\hline & GIF (Australia) & $=0.564$ & ESJI (KZ) & $=5.015$ & IBI (India) & $=4.260$ \\
\hline & JIF & $=1500$ & & & & \\
\hline
\end{tabular}

SOI: $\underline{1.1 / \text { TAS }}$ DOI: $\underline{10.15863 / \text { TAS }}$

International Scientific Journal Theoretical \& Applied Science

p-ISSN: 2308-4944 (print) e-ISSN: 2409-0085 (online)

Year: $2018 \quad$ Issue: 12 Volume: 68

Published: $12.12 .2018 \quad$ http://T-Science.org

UDC 631.354:633.1
QR - Issue

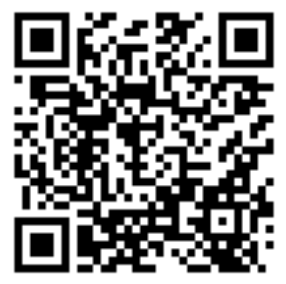

Kazakh National Agrarian University

Zh.S. Chingenzhinova Senior Lecturer,

Kazakh National Agrarian University

Zh.Zh. Kozhamkulova

Associate Professor,

Kazakh National Agrarian University

B.Zh. Kirgizbaeva

Associate Professor,

Kazakh National Agrarian University

E.S. Kulshikova

doctoral student,

Kazakh National Agrarian University

F.Kh. Raymbekova teacher

Kazakh National Agrarian University

\title{
ANALYSIS OF THE GRAIN MASS MOVEMENT IN THE FEEDER UNDER THE ACTION OF THE OPERATING ELEMENTS OF THE ACCELERATOR
}

Abstract: A design of a new type of threshing accelerator for a high-quality gathering of short dry crops is presented, which enhances the technological capabilities of the biomass distribution (equalization) to the width of the feeder due to the effect of a variable gap in the zone of the output edge of the harvester feeder. The process of movement of the dry short-stalked grain mass in the feeder with the threshing accelerator is considered. The principle of operation of the harvesting machine equipped with the threshing accelerator and its efficiency is described.

Key words: dry short-stalked grain mass, harvesting, threshing accelerator, grain mass movement along the corrugations.

Language: English

Citation: Baizakova, J. S., et al. (2018). Analysis of the grain mass movement in the feeder under the action of the operating elements of the accelerator. ISJ Theoretical \& Applied Science, 12 (68), 36-40.

Soi: http://s-o-i.org/1.1/TAS-12-68-6 Doi: crossef https://dx.doi.org/10.15863/TAS.2018.12.68.6

\section{Introduction}

The analysis of individual aspects that affect a high-performance, high-quality harvesting of grain crops shows that despite recent advances in science and practice, as well as improving harvesting techniques, a complete technological and technical support to harvesting is not provided, which would interconnect the variety of factors that determine a highly efficient use of equipment, complete gathering of harvest and preparation of high-quality products, because individual, sometimes original theoretical and practical solutions do not bring the desired effect. [1] 


\begin{tabular}{|c|c|c|c|c|c|c|}
\hline \multirow{4}{*}{ Impact Factor: } & ISRA (India) & $=3.117$ & SIS (USA) & $=0.912$ & ICV (Poland) & $=6.630$ \\
\hline & ISI (Dubai, UAF & $=0.829$ & РИНЦ (Russia) & $=0.156$ & PIF (India) & $=1.940$ \\
\hline & GIF (Australia) & $=0.564$ & ESJI (KZ) & $=\mathbf{5 . 0 1 5}$ & IBI (India) & $=4.260$ \\
\hline & JIF & $=1.500$ & SJIF (Morocco) & $=5.667$ & & \\
\hline
\end{tabular}

\section{Materials and Methods}

The right choice of combine harvesters is always important, and it goes far beyond the cost of the solution. The main criterion for evaluating the equipment is not the geography of its production, but quality and reliability of the machine in performing operations and services, and working conditions of the operator [2].

Scientists, engineers and inventors have proposed a set of recommendations for improving the design of combine harvesters and their controls, and have developed devices and applications that reduce both damage and injury to the grain. However, so far qualitative performance of combine harvesters that gather short dry crops do not meet the agro-technical requirements for the quality of the resulting product $[3,4]$.

To implement the mechanical-technological principle of the pre-threshing uniform distribution of the dry short-stalked grain mass by the transporting elements, we propose the threshing accelerator to be mounted on the harvester. The proposed threshing accelerator enhances technological capabilities of the biomass distribution (equalization) to the width of the feeder due to the effect of a variable gap in the zone of the outtake edge of the harvester feeder $[5,6,7]$.

Studies have shown that the distribution of the dry short-stalked grain mass is not uniform as the threshed flow is moving. Let us consider the process of movement of the dry short-stalked grain mass with a device installed in the feeder $[8,9,10]$.

The flow of the grain mass under continuous collisions with corrugations at the feeder inlet is a complex movement. It consists of the mass movement in the direction of the conveyor movement and the relative motion of the mass with velocity $u$ along the corrugation, or to the right (left corrugation) or to the left (right corrugation), which is shown in Fig. 1.

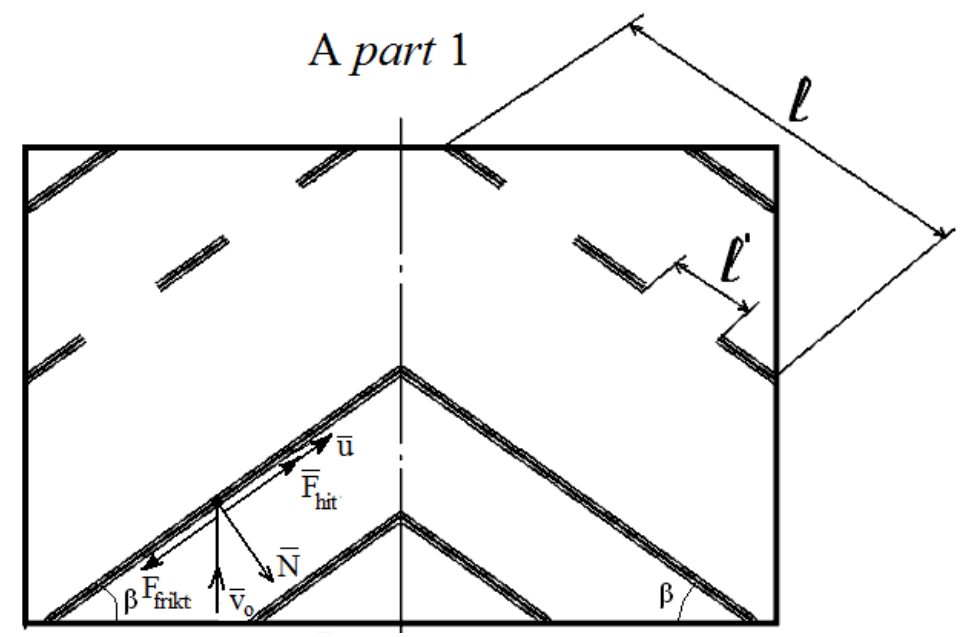

Fig. 1. Movement of the grain mass at the initial stage

At the time of movement, the grain mass leaves the corrugation, then the main stream covers, and later moves to the second corrugation (without discreteness), and then again interacts with the second corrugation similar to the first one. After overshooting the first corrugation (without discreteness), the relative speed " $u$ " of the stem directed along the guiding corrugation gradually reduces to zero. Here, the shock effects take place again, and the grain mass, due to a complex movement, shifts to the left or right, depending on the location of the corrugation. When the mass leaves the second corrugation (without discreteness), the diverted flow of the grain mass is moved further by the conveyor. Here, there are some changes in the absolute velocity of the grain mass. Then impact phenomena take place around the corrugations, and the grain mass shifts to the left or right due to a complex motion, depending on the location of the corrugation discreteness (Fig. 2) [11,12].

As the short-stalked grain mass moves, the underlying layers interact with discontinuous corrugations due to the shock pulse, and change their direction, i.e. move along the wall of the corrugation left and right. 


\begin{tabular}{|c|c|c|c|c|c|c|}
\hline \multirow{4}{*}{ Impact Factor: } & ISRA (India) & $=3.117$ & SIS (USA) & $=0.912$ & ICV (Poland) & $=6.630$ \\
\hline & ISI (Dubai, UAE & $=0.829$ & РИНЦ (Russia) & $=0.156$ & PIF (India) & $=1.940$ \\
\hline & GIF (Australia) & $=0.564$ & ESJI (KZ) & $=\mathbf{5 . 0 1 5}$ & IBI (India) & $=4.260$ \\
\hline & JIF & $=1.500$ & SJIF (Morocco) & $=5.667$ & & \\
\hline
\end{tabular}

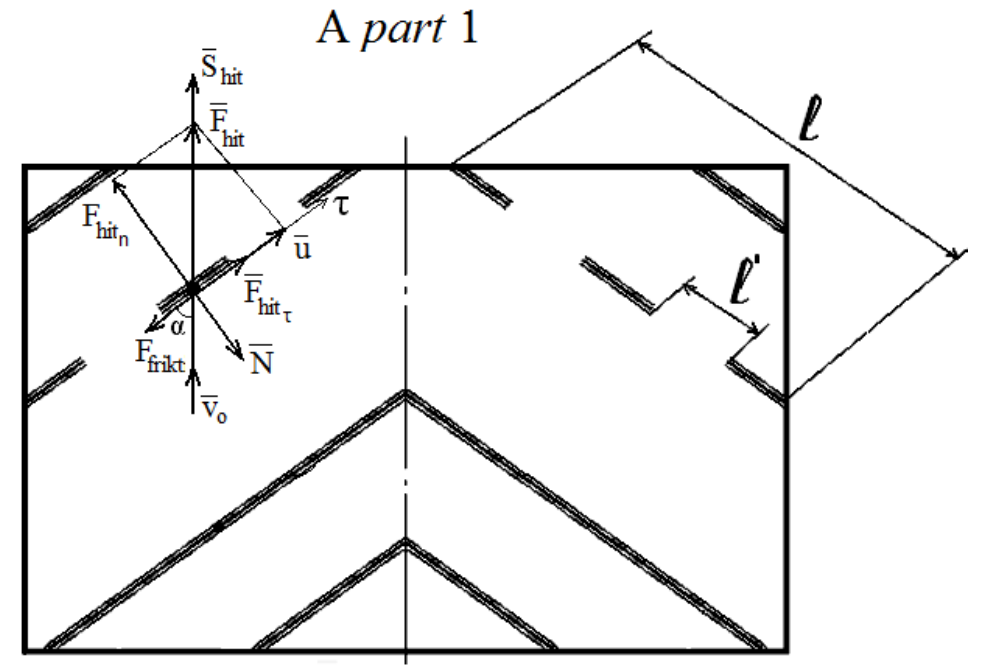

Fig. 2. Grain mass movement depending on the location of discreteness

Hereafter, due to the shock pulse, the grain mass begins to slide (move) left or right relative to the corrugation with velocity $\overline{u^{\prime}}$. At the time of movement of the grain mass to discreteness (the gap between the corrugations), it is picked up by a layer of the main stream, and there is a further move in the direction of the threshing machine. Scheme of the interaction can be seen in Figure 3.

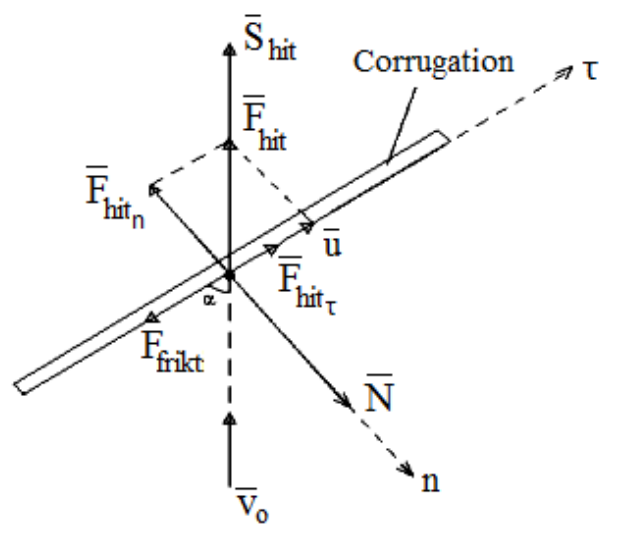

Fig. 3. Grain mass movement under a shock pulse

$$
\overline{S_{h i t}}=m \bar{u}-m \overline{v_{0}}: \bar{S}=\int_{0}^{\tau} \overline{F_{h i t}} d t
$$

where $\overline{v_{o}}$ is the velocity of the short dry grain mass at the time of approaching corrugations;

$\overline{S_{h i t}}$ is the shock pulse;

$\overline{F_{h i t}}$ is the impact force;

$\overline{F_{h i t \tau}}$ is the component of the impact force along the corrugations, which contributes to further movement of the mass along the corrugations;
$F_{h i t_{n}}$ is the component of the impact force along the principal normal, which induces the reaction force of the corrugation to the grain mass, i.e. $\overline{F_{h i t_{n}}}=\bar{N}$.

$F_{\text {friktion }}$ is the friction force arising at the time of the grain mass movement along the corrugation $F_{\text {friktion }}=f N$.

$$
\begin{gathered}
N=F_{h i t_{n}}=F_{h i t} \sin \alpha \\
F_{h i t_{\tau}}=F_{h i t} \cos \alpha
\end{gathered}
$$




\begin{tabular}{|c|c|c|c|c|c|c|}
\hline \multirow{4}{*}{ Impact Factor: } & ISRA (India) & $=3.117$ & SIS (USA) & $=0.912$ & ICV (Poland) & $=6.630$ \\
\hline & ISI (Dubai, UAE & $=0.829$ & РИНЦ (Russia) & $=0.156$ & PIF (India) & $=1.940$ \\
\hline & GIF (Australia) & $=0.564$ & ESJI (KZ) & $=\mathbf{5 . 0 1 5}$ & IBI (India) & $=4.260$ \\
\hline & JIF & $=1.500$ & SJIF (Morocco) & $=5.667$ & & \\
\hline
\end{tabular}

$$
F_{\text {friktion }}=f N=f F_{\text {hit }} \sin \alpha
$$

where $f$ is the coefficient of sliding and friction between the grain mass and the corrugation. $\alpha$ is the angle between the guiding corrugation and the direction of movement of the mass;

$N$ is the reaction force of the corrugation to the grain mass.

The grain mass moves along the corrugation, and in the first approximation we take this movement as progressive (Fig. 4).

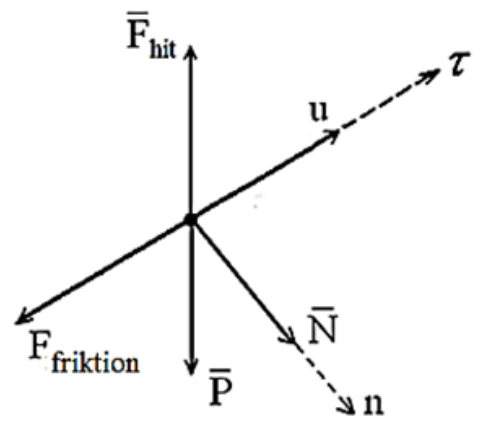

Fig. 4. Grain mass movement along the corrugation to discreteness

The dynamic equations of the grain mass movement along the corrugation to discreteness

$$
m \frac{\overline{d u}}{d t}=\overline{F_{\text {hit }}}+\bar{N}+\overline{F_{\text {friktion }}}+\bar{P}
$$

The differential equation of the grain mass movement

$$
m \frac{d^{2} s}{d t^{2}}=F_{h i t} \cos \alpha-F_{\text {friktion }}-P \sin \alpha
$$

where $s$ is the equation of the mass movement along the corrugation.

$$
\begin{gathered}
m \frac{d u}{d t}=F_{h i t} \cos \alpha-f F_{h i t} \sin \alpha \\
m \frac{d u}{d t}=F_{h i t}(\cos \alpha-f \sin \alpha)
\end{gathered}
$$

where $F_{\text {hit }_{\text {average }}}=\frac{S_{\text {hit }}}{\tau}$ is the average value of the impact force;

where $\tau$ is the infinitesimal interval of time, during which impact force acts.

Integrating equation (7), we obtain

$$
\int_{v_{0} \cos \alpha}^{u} d u=\frac{F_{\text {hit }_{\text {average }}}}{m}(\cos \alpha-f \sin \alpha) \int_{0}^{t} d t
$$

$$
u=v_{0} \cos \alpha+\frac{F_{\text {hit }_{\text {average }}}}{m}(\cos \alpha-f \sin \alpha) \cdot t
$$

Value $u$ is reduced to zero over time, since the difference $(\cos \alpha-f \sin \alpha)$ has a minus sign. Let us define the change in the grain mass along the corrugations by integrating equation (9)

$u=\frac{d s}{d t}=v_{0} \cos \alpha+\frac{F_{\text {hit }_{\text {average }}}}{m}(\cos \alpha-f \sin \alpha) \cdot t$

$\int_{0}^{s} d s=v_{0} \cos \alpha \int_{0}^{t} d t+\frac{F_{\text {hit }_{\text {average }}}}{m}(\cos \alpha-f \sin \alpha) \int_{0}^{t} t d t$

$s=v_{0} \cos \alpha \cdot t+\frac{F_{\text {hit }_{\text {average }}}}{m}(\cos \alpha-f \sin \alpha) \frac{t^{2}}{2}$

At the time of movement, the stalk leaves the corrugation, then the main stream covers the discreteness and moves along it, uniformly distributing further movement of the grain mass in the direction of the thresher $[13,14]$.

\section{Conclusion}

Thus, during the operation of the combine harvester, the stalks of the dry grain mass, as a result of moving through the feeder, interact with the discrete part of the corrugation and change their 


\begin{tabular}{|c|c|c|c|c|c|c|}
\hline \multirow{4}{*}{ Impact Factor: } & ISRA (India) & $=3.117$ & SIS (USA) & $=0.912$ & ICV (Poland) & $=6.630$ \\
\hline & ISI (Dubai, UAE & $=0.829$ & РИНЦ (Russia) & $=0.156$ & PIF (India) & $=1.940$ \\
\hline & GIF (Australia) & $=0.564$ & ESJI (KZ) & $=\mathbf{5 . 0 1 5}$ & IBI (India) & $=4.260$ \\
\hline & JIF & $=1.500$ & SJIF (Morocco) & $=5.667$ & & \\
\hline
\end{tabular}

direction, getting into the threshing apparatus in a more stream-lined flow.

\section{References:}

1. Sadykov, Z. S., et al. (2010). Threshing accelerator for reapers. Opinion on the issue of the innovative patent based on application №2010/0465.1.

2. Baizakova, Z. S. (2013). The parameters of the device for the normalization of the grain mass in the inclined chamber of the combine before threshing dry short-stem crops. author. Candidate of Technical Sciences:.01.03.03. (p.17). Novosibirsk: GNU SibIME.

3. Sadykov, Z. S., Baizakova, Z. S., Toylybaev, M. S., Sultangaziyev, K. K., \& Sultangaziyev, T. K. (2016). Upgrading the Efficiency of Harvesting Machines by Means of Thrashing Accelerator of a New Type. International Journal of Applied Engineering Research ISSN 0973-4562 Volume 11, Number 16, 89668970. (C) Research India Publications. http://www.ripublication.com

4. Bajzakova, Z. S., \& Chingenzhinova, Z. S. (2015). Usovershenstvovanie processa obmolota suhih korotkostebel'nyh zernovyh kul'tur. Nauchnyj zhurnal «Issledovanija $i$ rezul'taty», №04 (068), Almaty: KazNAU, 207-210.

5. Babenko, J. P., \& Chernecskij, G. B. (1971). O vlijanii neravnomernosti podachi na poteri zerna molotilkoj. Zapiski LSHI, T.164, vyp. 1, L..

6. Zhalnin, J. V., \& Savchenko, A. N. (1985). Tehnologii uborki zernovyh kombajnovymi agregatami. (p.207). M.: Rossel'hozizdat.

7. (1981). Ispytanija sel'skohozjajstvennoj tehniki. Mashiny zernouborochnye. Programma i metody ispytanij. OST 70.8.1-81.
8. (1968). KubNIITIM. Metodika agrotehnicheskoj ocenki mashin $i$ prisposoblenij dlja uborki zernovyh, kolosovyh $i$ zernobobovyh kul'tur. Moscow.

9. Penkin, M. G. (1988). Novye tehnologii uborki zernovyh kl'tur. (p.277). Alma-Ata: Kajnar.

10. Pugachev, A. N. (1980). Kontrol' kachestva uborki zernovyh kul'tur. (p.255). M.: Kolos.

11. Bajzakova, Z. S. (2012). Analiz processa dvizhenija hlebnoj massy v naklonnoj kamere pod vozdejstviem rabochih organov uskoritelja. Sibirskij vestnik sel'skohozjajstvennoj nauki. Novosibirsk, №2 (225), 116-121.

12. Bajzakova, Z. S. (2012). Optimal'nye parametry rezhimov raboty ustrojstva dlja uborki suhih korotkostebel'nyh zernovyh kul'tur. Vestnik NGAU, Novosibirsk, №3 (24), 92-95.

13. Bajzakova, Z. S., \& Chingenzhinova, Z. S. (2017). K usovershenstvovaniju tehnicheskih sredstv dlja uborki suhih korotkostebel'nyh zernovyh kul'tur. Aktual'nye nauchnye issledovanija $\mathrm{v}$ sovremennom mire. HHVII Mezhdunar. nauchn. konf., 26-27 ijulja 2017 g., Perejaslav-Hmel'nickij. // Sb. nauchnyh trudov Perejaslav-Hmel'nickij, 2017. - Vyp. 7(27), ch. pp.20 - 25.

14. Bajzakova, Z. S., \& Chingenzhinova, Z. S. (2017). Opredelenie ravnomernosti dvizhenija hlebnoj massy $v$ naklonnoj kamere. Aktual'nye nauchnye issledovanija $\mathrm{v}$ sovremennom mire: HHVII Mezhdunar. nauchn. konf., 26-27 ijulja 2017 g., Perejaslav-Hmel'nickij. // Sb. nauchnyh trudov - Perejaslav-Hmel'nickij, 2017. - Vyp. 7(27), ch. pp.25 -31. 